\begin{tabular}{|l|l|}
\hline $\begin{array}{l}\text { 2. To: (Receiving Organization) } \\
\text { Distribution }\end{array}$ & $\begin{array}{l}\text { 3. From: (Originating Organization) } \\
\text { RPP Radiological Control }\end{array}$ \\
\hline $\begin{array}{l}\text { 5. Proj./Prog./Dept./Div: } \\
\text { Radiological Engineering }\end{array}$ & $\begin{array}{l}\text { 6. Design Authority/Design Agent/Cog. Engr.: } \\
\text { T. A. Shoemaker }\end{array}$ \\
$\begin{array}{l}\text { 8. Originator Remarks: } \\
\text { Analysis of East Tank Earms Contamination Survey Frequency is being } \\
\text { issued as RPP-6757 to provide the justification for performing } \\
\text { monthly contamination surveys in occupied contamination areas. }\end{array}$
\end{tabular}

11. Receiver Remarks:

11A. Design Baseline Document? $\bigcirc$ Yes

O No
16.

\begin{tabular}{|c|}
\hline Approval Designator (F) \\
\hline E, S, Q, D OR N/A \\
(See WHC-CM-3-5, \\
Sec. 12.7) \\
\hline
\end{tabular}

17

\begin{tabular}{|c|c|c|c|}
\hline \multicolumn{4}{|c|}{$\begin{array}{l}\text { 4. Related EDT No.: } \\
\text { N / A }\end{array}$} \\
\hline \multicolumn{2}{|c|}{$N / A$} & & \\
\hline \multicolumn{4}{|c|}{$\begin{array}{l}\text { 9. Equip./Component No.: } \\
\text { N/A }\end{array}$} \\
\hline \multicolumn{4}{|c|}{$\begin{array}{l}\text { 10. System/Bldg./Facility: } \\
\text { RPP }\end{array}$} \\
\hline \multicolumn{4}{|c|}{$\begin{array}{l}\text { 12. Major Assm. Dwg. No.: } \\
\text { N/A }\end{array}$} \\
\hline \multicolumn{4}{|c|}{$\begin{array}{l}\text { 13. Permit/Permit Application No.: } \\
\text { N/A }\end{array}$} \\
\hline \multicolumn{4}{|c|}{$\begin{array}{l}\text { 14. Required Response Date: } \\
\text { N/A }\end{array}$} \\
\hline$(F)$ & (G) & $(\mathrm{H})$ & (l) \\
\hline $\begin{array}{l}\text { Approval } \\
\text { Desig- } \\
\text { nator }\end{array}$ & $\begin{array}{c}\text { Reason } \\
\text { for Trans- } \\
\text { mittal }\end{array}$ & $\begin{array}{c}\text { Origi- } \\
\text { nator } \\
\text { Dispo- } \\
\text { stion }\end{array}$ & $\begin{array}{l}\text { Receiv- } \\
\text { er } \\
\text { Dispo- } \\
\text { sition }\end{array}$ \\
\hline$N / A$ & 2 & 1 & \\
\hline & & & \\
\hline & & & \\
\hline & & & \\
\hline & & & \\
\hline & & & \\
\hline & & & \\
\hline
\end{tabular}

KEY

\section{DATA TRANSMITTED}

\begin{tabular}{ll|l} 
(C) Sheet & (D) Rev. & (E) Title or Description of Data Transmitted \\
No. & (E)
\end{tabular}
Analysis of East Tank Farms Contamination Survey Erequency
Reason for Transmittal (G)

4. Review
5. Post-Review
6. Dist. (Receipt Acknow. Required)

Disposition (H) \& (I)

\begin{tabular}{|ll}
\hline \multicolumn{2}{|c}{ Disposition (H) \& (I) } \\
$\begin{array}{ll}\text { 1. Approved } & \text { 4. Reviewed no/comment } \\
\text { 2. Approved w/comment } & \text { 5. Reviewed w/comment } \\
\text { 3. Disapproved w/comment } & \text { 6. Receipt acknowledged }\end{array}$ \\
\hline
\end{tabular}

SIGNATURE/DISTRIBUTION

(See Approval Designator for required signatures)

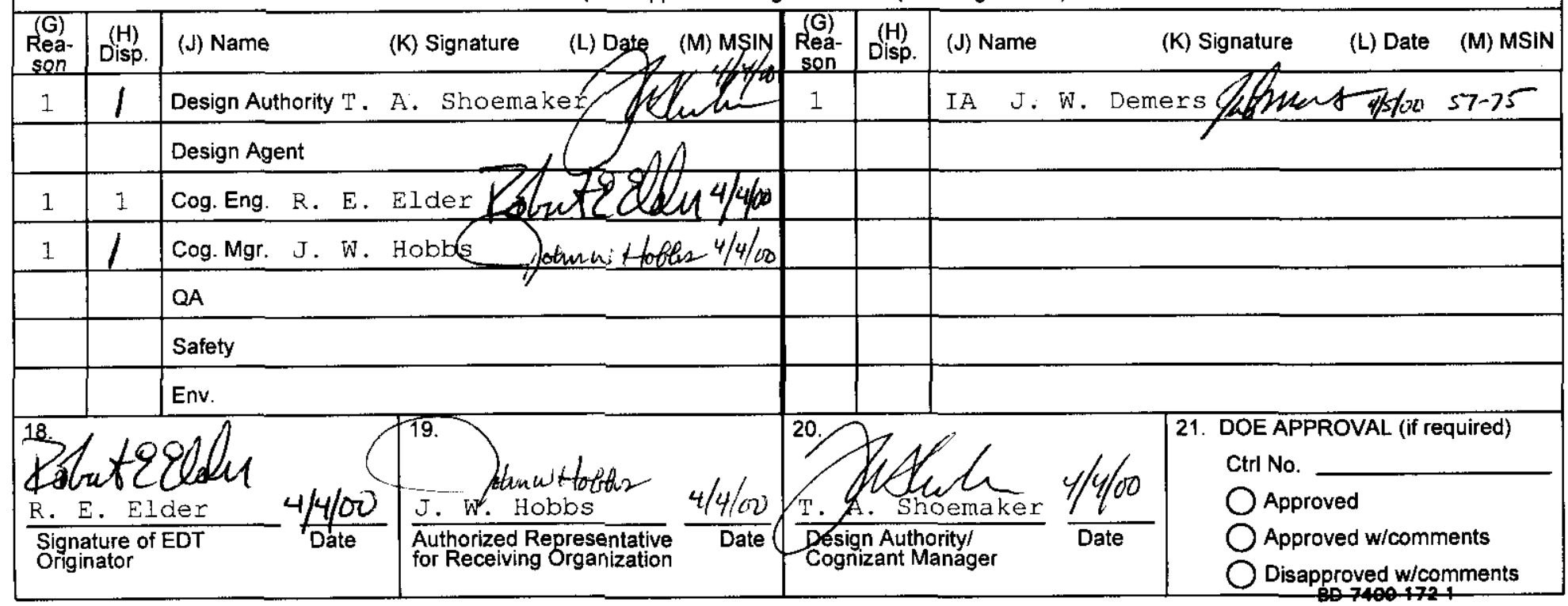




\section{Analysis of East Tank Farms Contamination Survey Frequency}

R. E. Elder

CH2M HILL Hanford Group

Richland, WA 99352

U.S. Department of Energy Contract DE-AC06-96RL13200

$\begin{array}{lll}\text { EDT/ECN: } & \text { EDT-622096 } & \text { UC: } 2080 \\ \text { Org Code: } & 79700 & \text { Charge Code: } 102586 \\ \text { B\&R Code: } & \text { N/A } & \text { Total Pages: } 7\end{array}$

Key Words: River Protection Project; Survey Frequency; Contamination Area; East Tank Farm

Abstract: This document provides the justification for the change in survey frequency in East Tank Farms occupied contamination areas from weekly to monthly.

TRADEMARK DISCLAIMER. Reference herein to any specific commercial product, process, or service by trade name, trademark, manufacturer, or otherwise, does not necessarily constitute or imply its endorsement, recommendation, or favoring by the United States Government or any agency thereof or its contractors or subcontractors.

Printed in the United States of America. To obtain copies of this document, contact: Document Control Services, P.O. Box 950, Mailstop H6-08, Richland WA 99352, Phone (509) 372-2420; Fax (509) 376-4989.
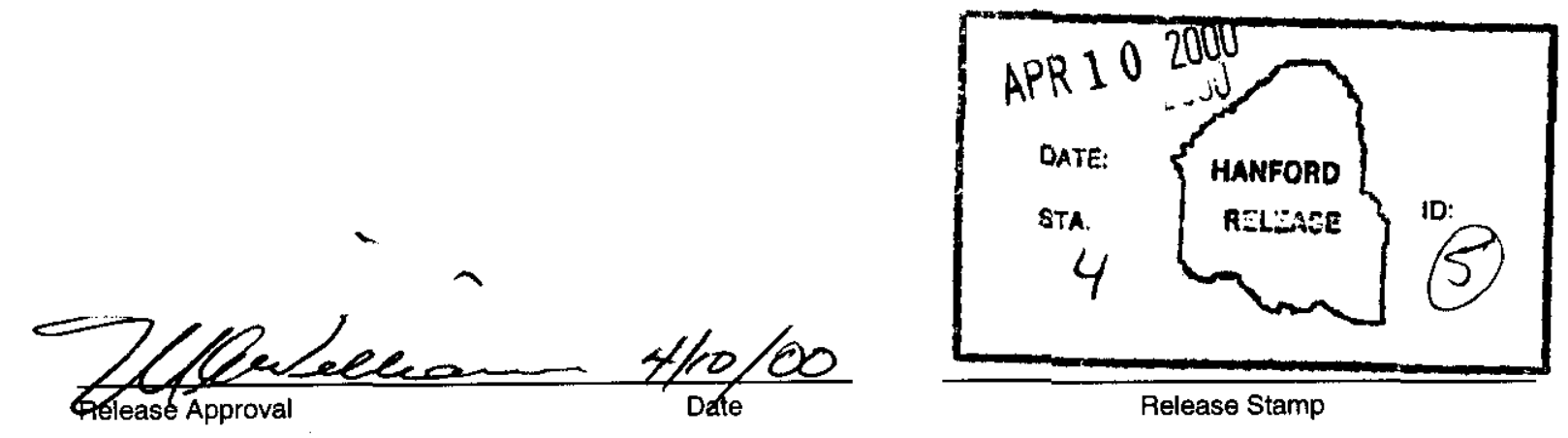

\section{Approved For Public Release}




\subsection{Background}

The Tank Farms Radiological Control Organization has performed radiological surveys of its Contamination Area (CA) Double Shell Tank (DST) farms in 200 East Area on a weekly basis for several years. The task package (DST-W012) controlling these routines designates specific components, at a minimum, that must be surveyed whenever the task is performed. This document documents the evaluation of these survey requirements and provides the recommendation and basis for moving DST tank farms in the 200 East Area from a weekly to monthly contamination survey.

The contamination surveys for occupied contamination areas in West Tank Farms (WTF) were changed from a weekly frequency to a monthly frequency in 1997. Review of contamination survey data in WTF indicates a monthly interval remains satisfactory.

\subsection{Summary of Requirements and Implementation}

The frequency for contamination surveys is set in HSRCM Articles 551 and 554, specifically,

HSRCM 551.3. Surveys for radiation, contamination and airborne radioactive materials shall be performed as specified in Technical Work Documents and Radiological Work Permits (RWP).

Implementation Work related surveys as defined in this are not relative to the frequency of Routine Surveys, unless there is demonstrable data to indicate such surveys are not being performed.

HSRCM 551.6. Assessment of radiological conditions should include a sufficient number of survey points to characterize the radiation present and to verify boundaries.

Implementation This is clearly met on two levels, one the current routine program in East Tank Farms (ETF) is exemplary in that it characterizes the work place very efficiently; and two, the current boundaries of occupied contamination areas are being surveyed on a weekly basis.

HSRCM 551.7. Surveys should be performed before, during and at the completion of work that has the potential for causing changes in levels of radiation and radioactivity.

Implementation As noted on 551.3 above, this is a function of work related surveys. If we are not performing these surveys, then the frequency for contamination surveys must be weekly. However, the current programs in place require that these surveys be performed before, during and after the performance of work involving the opening of potentially contaminated systems. RWPs (such as TF-001, TF-014 and job specific RWPs) are written with these Health Physics Technician (HPT) coverage requirements. 
HSRCM 551.8. Survey frequencies should be established based on potential radiological conditions, probability of change in conditions and area occupancy factors.

Implementation Survey data from the East Tank Farm facilities is very clear in establishing three key facts: East Tank Farm Facilities have very few areas of actual contamination, the contamination levels are low, and the contamination is not showing any indication of increasing from historical levels.

HSRCM 551.12. Monitoring data in each building or area should be compiled and reviewed at least quarterly. Changes or trends should be noted and corrective actions assigned.

Implementation This implies that we need to do our surveys as a minimum on a quarterly frequency; the monthly surveys will provide more than enough information to meet this requirement.

HSRCM 554.1.g In addition to the requirements of Article 551, routine contamination surveys should be conducted in Radiological Buffer Areas (RBA) established for the control of contamination and other areas with the potential for spread of contamination as follows:

g. Weekly, or upon entry if entries are less frequent, in areas where radioactive materials are handled or stored

Implementation: It was the determination of the Interpretive Authority that this requirement was not necessarily applicable to contamination areas (INTR-9705-SVY-0236). The text of the communication from the Interpretive Authority is as follows:

Most of the provisions are clear and self-explanatory, but in the case of $554.1(\mathrm{~g})$, "other areas with the potential for the spread of contamination" and "where radioactive material is handled or stored." Surface contamination is not material that is "handled or stored" as handling or storage imply some active manipulation. Work that does not involve handling of radioactive material, such as tours or use of non-contaminated material or equipment would not require a weekly survey under $554.1(\mathrm{~g})$, though contamination surveys may be required according to Articles 551.3, 551.7 , or 551.8, as you determine. As I understand it, your documented survey history adequately establishes a basis for your current frequency for routine surveys in Contamination Areas according to Article 551.12.

10CFR835 Subpart E-Monitoring of Individuals and Areas $\S 835.401$ General requirements (Pertinent subsections are listed below)

(a) Monitoring of individuals and areas shall be performed to:

2) Document radiological conditions;

3) Detect changes in radiological conditions; 
4) Detect the gradual buildup of radioactive material;

5) Verify the effectiveness of engineering and process controls in containing radioactive material and reducing radiation exposure;

Implementation The 10CFR835 requirements are implemented through the CH2M HILL Hanford Group (CHG) Radiation Protection Program (RPP), HNF-MP5184. This document includes those items committed to by CHG to ensure regulatory compliance, and is approved by the Department of Energy.

\subsection{Supporting Analysis}

A review of the data from the weekly surveys has established that the area contamination levels have been adequately characterized. It has shown, for instance, that in 241-AY Tank Farm there has only rarely been instances of removable contamination levels greater than $1,000 \mathrm{dpm}$ found $98.6 \%$ of the surveys points since November 1999 have been $<1,000 \mathrm{dpm}$. The other tank farms have all shown similar results (see table below). Complete data is shown in attachment 1 .

\begin{tabular}{|l|l|l|l|}
\hline Tank Farm & $\begin{array}{l}\text { Percent of surveys } \\
\text { at }<1,000 \mathrm{dpm}\end{array}$ & $\begin{array}{l}\text { Percent of surveys } \\
\text { at } 1,000-10,000 \\
\mathrm{dpm}\end{array}$ & $\begin{array}{l}\text { Percent of surveys } \\
\text { at }>10,000 \mathrm{dpm}\end{array}$ \\
\hline \hline $241-\mathrm{A}$ & $88 \%$ & $11 \%$ & $1 \%$ \\
\hline $241-\mathrm{AX}$ & $94 \%$ & $5 \%$ & $1 \%$ \\
\hline $241-\mathrm{AY}$ & $99 \%$ & $<1 \%$ & $1 \%$ \\
\hline $241-\mathrm{AZ}$ & $95 \%$ & $4 \%$ & $1 \%$ \\
\hline $241-\mathrm{C}$ & $94 \%$ & $6 \%$ & $<1 \%$ \\
\hline
\end{tabular}

Current work planning practice (through procedure and RWP) is to require surveys prior to the opening of potentially contaminated systems, and before, during and after the completion of work that has the potential to cause a change in radiation and/or radioactivity levels (Article 551 requirement). Work packages require that the work area be restored to the pre-job (or better) conditions. This practice ensures that activities with the potential to spread contamination are surveyed as part of the process.

In reviewing the weekly survey data since the end of October 1999, it was found that the majority of the individual areas surveyed have consistently shown levels $<1,000 \mathrm{dpm}$. On a week to week basis, they have shown that the contamination levels are low, and that there is no indication that the levels are increasing over the historical levels.

However, there have been a few risers that, over the past four months, have shown elevated levels fairly consistently. These risers are: 

A Tank Farm
102-A, Riser \#2 ( 5 out of 19 points $>1,000 \mathrm{dpm}$ )
104-A, Riser \#4 (7 out of 17 points $>1,000 \mathrm{dpm}$ )
$106-\mathrm{A}$, Riser \#6 (6 out of 19 points $>1,000 \mathrm{dpm}$ )
C Tank Farm
$104-C$, Riser $\# 8$ ( 4 out of 19 points $>1,000 \mathrm{dpm}$ )
$111-\mathrm{C}, 12$ " Riser (5 out of 19 points > 1,000 dpm)

In addition, one riser in C Tank Farm that is not routinely monitored (104-C, Riser \#7) has shown removable contamination in four out of the previous seventeen weeks.

An additional area of concern is the existence of small isolated high contamination areas in the east tank farm facilities. The current program does not include boundary verification for these areas. Any program improvements or change in frequency needs to include boundary verification of high contamination areas located within the areas being surveyed.

\subsection{Other Potentially Applicable Requirements}

The DOE Radiological Control Standard (DOE-STD-1098-99) has been approved and has changed the criteria found in Articles 551 and 554. The changes to the general requirements in article 551 are not specifically applicable, however the change to article 554 requires addressing.

DOE-STD-1098-99 states the following in article 554, Contamination Monitoring

1. In addition to the requirements of Article 551, contamination monitoring programs should be established to ensure that surveys are performed at a frequency that is consistent with the existing and potential hazards and activities planned in the area. The following survey frequencies are suggested and should be modified as necessary to ensure area hazards are adequately characterized, based on facility-specific experience

h. Weekly, or upon entry if entries are less frequent, in contamination areas and other areas where materials having removable contamination exceeding the Table $2-2$ values are handled or stored.

Implementation: The frequencies noted above are unnecessarily conservative when considering the potential hazards and activities planned in the area. The potential hazard is exposure to contamination. As work activities that are taking place in the facility are all closely monitored as required by current River Protection Project (RPP) RWPs, the potential for exposure to contamination above permissible levels due to monthly contamination surveys over weekly contamination levels is remote. Monthly contamination surveys are adequate to ensure area hazards are adequately characterized under the current system where all work activities that open contaminated systems are covered by an RWP that requires HPT coverage. 


\subsection{Conclusions and Recommendations}

In conclusion, the data clearly shows that the current routine program in East Tank Farms has characterized the work place effectively and that the contamination levels are low, and not showing any indication of increasing from historical levels. There are few (6) risers that have shown removable contamination with any regularity. The standard of requiring pre and post job surveys of opening potentially contaminated systems has keep the CA tank farms relatively free of loose contamination.

The recently (August1999) completed Management Strategies, Inc. (MSI) RadCon Requirements Based Surveillance and Maintenance (RBSM) Assessment supports moving the routine frequency from weekly to monthly. In their comments about CA tank farm survey frequency, they state that "...management should consider the feasibility of moving the CA surveillance to monthly (as performed in the West Tank Farms) if the conditions in the East Tank Farms allow."

The areas being surveyed need to address the presence of high contamination area boundary verification as part of the scheduled survey task descriptions.

Based on the data gathered and analyzed from the weekly contamination surveys, the HSRCM Article interpretation, and the MSI RBSM Assessment suggestions, it is recommended that the survey frequency for the 200 East Area CA tank farms be immediately changed from a weekly to monthly scheduled surveillance. This would allow needed resources to be deployed elsewhere, without jeopardizing employee health and safety. 


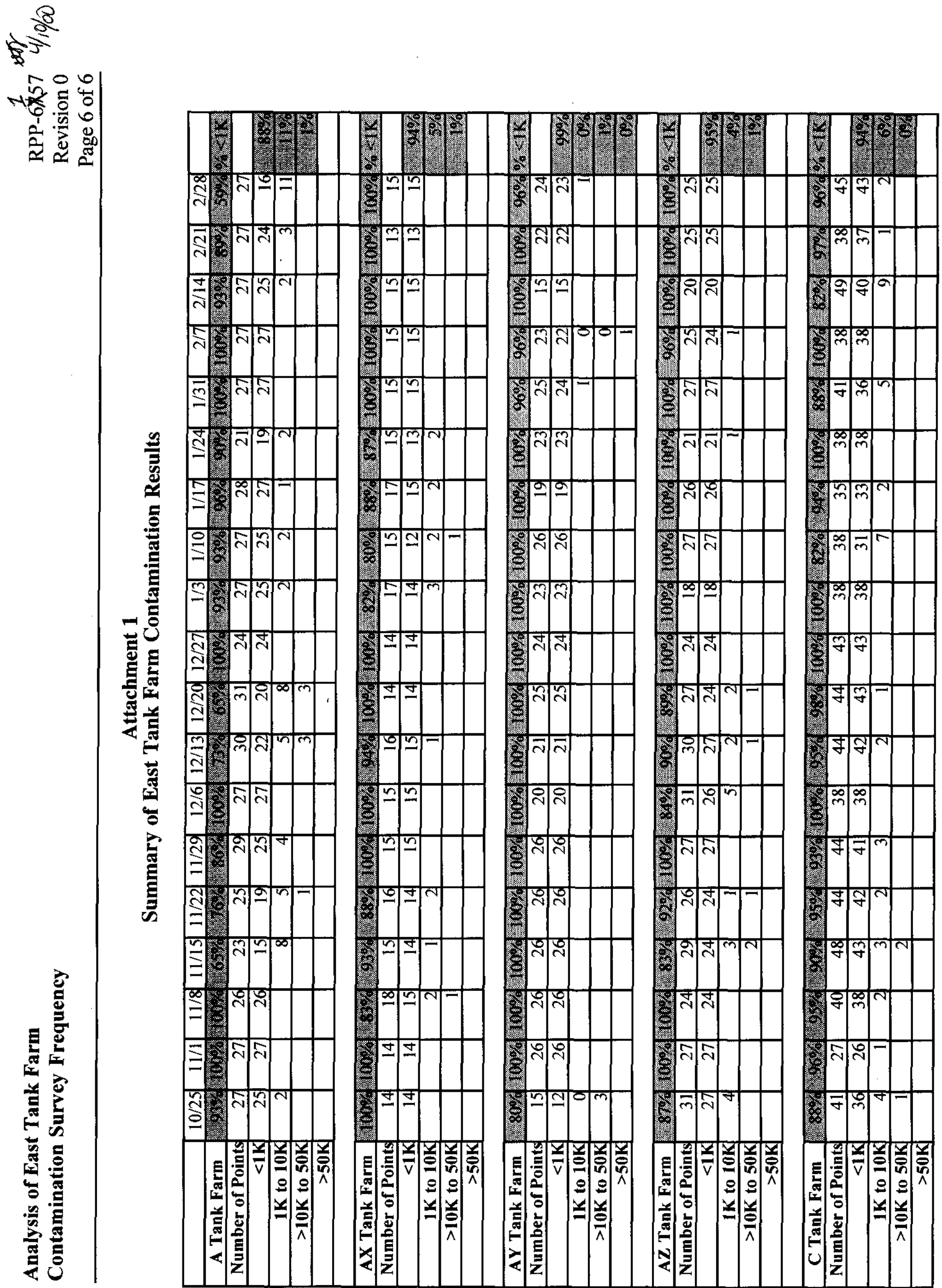




\section{DISTRIBUTION SHEET}

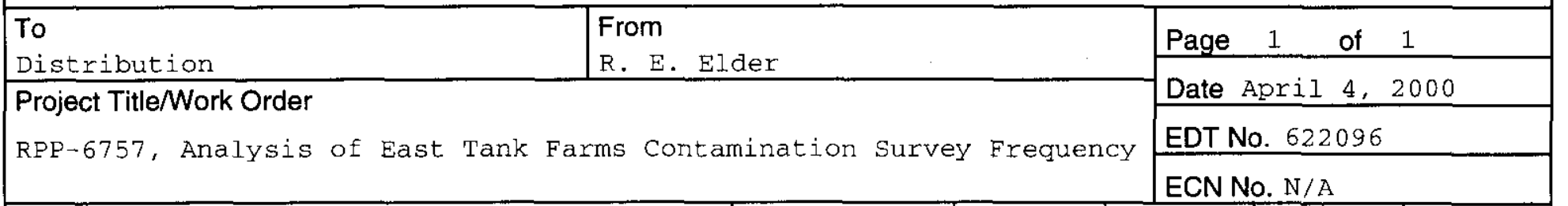

\begin{tabular}{|c|c|c|c|c|c|}
\hline Name & MSIN & $\begin{array}{c}\text { Text } \\
\text { With All } \\
\text { Attach. }\end{array}$ & Text Only & $\begin{array}{l}\text { Attach./ } \\
\text { Appendix } \\
\text { Only }\end{array}$ & $\begin{array}{c}\text { EDT/ECN } \\
\text { Only }\end{array}$ \\
\hline E. E. Bickel & $\$ 7-75$ & $x$ & & & \\
\hline K. W. Gray & $57-75$ & $\mathrm{X}$ & & & \\
\hline J. W. Hobbs & $\$ 7-75$ & $X$ & & & \\
\hline E. E. Kennedy & $S 7-75$ & $x$ & & & \\
\hline T. A. Shoemaker & $57-75$ & $\mathrm{X}$ & & & \\
\hline C. E. Upchurch & $S 7-75$ & $x$ & & & \\
\hline L. G. Berry & $s 7-75$ & $\mathrm{x}$ & & & \\
\hline R. I. Brown & $S 7-75$ & $\mathrm{x}$ & & & \\
\hline K. R. Dunn & $57-75$ & $x$ & & & \\
\hline R. E. Elder & $S 7-75$ & $\mathrm{x}$ & & & \\
\hline D. J. Foust & $57-75$ & $x$ & & & \\
\hline M. J. Kornish & $57-75$ & $\mathrm{x}$ & & & \\
\hline J. J. O'Connor & $S 7-75$ & $\mathrm{x}$ & & & \\
\hline S. H. Pearce & $57-75$ & $x$ & & & \\
\hline R. M. Pierson & $57-75$ & $\mathrm{x}$ & & & \\
\hline C. P. Seilhymer & $57-75$ & $\mathrm{x}$ & & & \\
\hline R. J. Thomas & $57-75$ & $\mathrm{x}$ & & & \\
\hline J. W. DeMers & $57-75$ & $\mathrm{x}$ & & & \\
\hline S. H. Waters & $\$ 5-07$ & $x$ & & & \\
\hline R. B. Buckner & $55-02$ & $\mathrm{x}$ & & & \\
\hline G. M. Davis & $T 4-01$ & $\mathrm{x}$ & & & \\
\hline J. W. Sumlin & $S 5-02$ & $\mathrm{x}$ & & & \\
\hline R. J. Reeder & $S 7-05$ & $\mathrm{x}$ & & & \\
\hline J. M. McAuley & $55-49$ & $\mathrm{x}$ & & & \\
\hline & & & & & \\
\hline & & & & & \\
\hline & & & & & \\
\hline & & & & & \\
\hline & & & & & \\
\hline & & & & & \\
\hline & & & & & \\
\hline
\end{tabular}

